\title{
THE DIGITAL CIRCULATION IN PERIPHERAL VASCULAR DISEASES
}

\author{
By MILTON MENDLOWITZ \\ (From the Medical Services of The Mount Sinai Hospital, New York)
}

(Received for publication April 2, 1942)

In a previous communication (1), methods were described for studying the digital blood flow, blood pressure, and vascular resistance in normal subjects and in patients with hypertension and coronary thrombosis. These methods have been applied to the investigation of Raynaud's syndrome, scleroderma, and thrombo-angiitis obliterans involving the upper extremities.

\section{RESULTS}

The results are presented in Table I. In three cases of typical Raynaud's disease, one of less than one year's duration, and the others of less than extreme decrease in digital blood flow to approximately four per cent of the normal, with a correspondingly extreme increase in digital vascular resistance to the height of 1740 units (normal 63 to 96 units). The digital arterial blood presure was somewhat low and the brachial-digital arterial pressure gradient moderately increased.

Seven cases of scleroderma were studied. In one case (C. R.) only the neck, chest, face, and legs were involved, there being no perceptible sclerodactyly. In this case, the digital blood flow was at the lower limit and the digital vascular resistance at the upper limit of normal. In the

TABLE I

Peripheral vascular diseases

\begin{tabular}{|c|c|c|c|c|c|c|c|}
\hline \multirow[b]{2}{*}{ Patient } & \multirow[b]{2}{*}{ Age and sex } & \multirow[b]{2}{*}{ Diagnosis } & \multirow[b]{2}{*}{ Duration } & \multicolumn{4}{|c|}{ After body warming } \\
\hline & & & & $\begin{array}{l}\text { Brachial } \\
\text { blood } \\
\text { pressure }\end{array}$ & $\begin{array}{l}\text { Digital } \\
\text { blood } \\
\text { pressure }\end{array}$ & $\begin{array}{l}\text { Digital } \\
\text { blood } \\
\text { flow }\end{array}$ & $\begin{array}{c}\text { Digital } \\
\text { vascular } \\
\text { resistance }\end{array}$ \\
\hline & & & & $m m . H g$ & mm. $H_{8}$ & $\begin{array}{l}\text { cc. per } \\
\text { sq. cm. per } \\
\text { minute }\end{array}$ & units \\
\hline $\begin{array}{l}\text { R. N. } \\
\text { P. B. } \\
\text { R. B. }\end{array}$ & $\begin{array}{l}52 \mathrm{~F} \\
23 \mathrm{~F} \\
46 \mathrm{~F}\end{array}$ & $\begin{array}{l}\text { Raynaud's disease } \\
\text { Raynaud's disease } \\
\text { Raynaud's disease }\end{array}$ & $\begin{array}{l}2 \text { years } \\
2 \text { years } \\
\text { Less than }\end{array}$ & $\begin{array}{l}128 / 75 \\
112 / 78 \\
122 / 82\end{array}$ & $\begin{array}{l}110 / 66 \\
110 / 65 \\
110 / 68\end{array}$ & $\begin{array}{l}0.22 \\
0.20 \\
0.19\end{array}$ & $\begin{array}{l}112 \\
123 \\
132\end{array}$ \\
\hline F. S. & $45 \mathrm{M}$ & $\begin{array}{l}\text { Raynaud's syndrome; secondary } \\
\text { sclerodactyly }\end{array}$ & $\begin{array}{l}1 \text { year } \\
7 \text { years }\end{array}$ & $116 / 84$ & $74 / 54 ?$ & 0.01 & 1740 \\
\hline $\begin{array}{l}\text { C. R. } \\
\text { J. S. }\end{array}$ & $\begin{array}{l}39 \mathrm{~F} \\
49 \mathrm{~F}\end{array}$ & $\begin{array}{l}\text { Scleroderma; no sclerodactyly } \\
\text { Scleroderma; essential hyperten- } \\
\text { sion }\end{array}$ & $?$ & $\begin{array}{l}102 / 72 \\
198 / 118\end{array}$ & $\begin{array}{r}96 / 68 \\
182 / 90\end{array}$ & $\begin{array}{l}0.23 \\
0.14\end{array}$ & $\begin{array}{r}99 \\
279\end{array}$ \\
\hline $\begin{array}{l}\text { F. U. } \\
\text { L. E. } \\
\text { D. C. } \\
\text { H. T. } \\
\text { E. S. } \\
\text { I. S. } \\
\text { W. D. }\end{array}$ & $\begin{array}{l}37 \mathrm{~F} \\
51 \mathrm{~F} \\
43 \mathrm{~F} \\
56 \mathrm{M} \\
48 \mathrm{~F} \\
33 \mathrm{M} \\
32 \mathrm{M}\end{array}$ & $\begin{array}{l}\text { Scleroderma } \\
\text { Scleroderma } \\
\text { Scleroderma } \\
\text { Scleroderma } \\
\text { Scleroderma } \\
\text { Thrombo-angiitis obliterans } \\
\text { Thrombo-angiitis obliterans }\end{array}$ & $\begin{array}{l}6 \text { months } \\
9 \text { years? } \\
5 \text { years } \\
5 \text { years } \\
13 \text { years } \\
3 \text { years } \\
3 \text { years }\end{array}$ & $\begin{array}{r}126 / 88 \\
125 / 65 \\
94 / 58 \\
120 / 90 \\
112 / 74 \\
120 / 82 \\
128 / 88\end{array}$ & $\begin{array}{l}108 / 62 \\
110 / 45 \\
68 / 55 \\
90 / 65 \\
58 / 48 \\
35 / 25 ? \\
65 / 54\end{array}$ & $\begin{array}{l}0.19 \\
0.14 \\
0.09 \\
0.02 \\
0.03 \\
0.13 \\
0.15\end{array}$ & $\begin{array}{r}126 \\
153 \\
186 \\
1080 \\
470 \\
54 \\
105\end{array}$ \\
\hline
\end{tabular}

two, the digital blood flow was below the lower limit of normal, and the digital vascular resistance definitely elevated in each case. The digital blood pressures and the brachial-digital pressure gradients, on the other hand, were normal. In a case of Raynaud's syndrome of seven years' duration in a male, with secondary sclerodactyly and incipient necrosis of the finger tips, there was an other six cases, in which the scleroderma was accompanied by sclerodactyly, there was a uniform decrease in digital blood flow and an increase in digital vascular resistance. The extent of these changes was roughly proportional to the duration of the disease. In the two most advanced cases, there was also a moderate decrease in digital arterial pressure and a corresponding increase in 
the brachial-digital arterial pressure gradient. In one of the cases of scleroderma and sclerodactyly, there was associated essential hypertension which was not in the acute or malignant stage. The digital blood flow in this case, however, was decreased, and the vascular resistance was elevated beyond the level commensurate with the degree of hypertension (1).

In two cases of thrombo-angiitis obliterans with upper extremity involvement, the digital arterial blood pressure was very low in both. There was a corresponding pronounced increase in the brachial-digital arterial pressure gradient. The digital blood flow in each case was decreased in proportion to the decrease in digital arterial pressure, the digital vascular resistance being comparatively normal. There were no changes in digital vascular resistance in any way comparable to those found in Raynaud's disease or scleroderma.

\section{DISCUSSION}

In these investigations, the circulation in the finger tip was studied after release of sympathetic tone by immersion of the contralateral upper extremity in a water bath, kept between forty-three and forty-five degrees Centigrade, and stirred until generalized sweating was well advanced. At this stage of vasodilatation Lewis and Pickering (2) were unable to effect any significant increase in the temperature of the fifth finger by novocaine injection of the ulnar nerve. The effect of body warming in releasing sympathetic vasoconstrictor nerve tone has also been shown to be operative in cases of Raynaud's disease and scleroderma (3, 4). Our results, therefore, represent the fixed irreversible changes in the digital circulation unaffected by fluctuations in vasoconstrictor nerve tone.

The decreased blood flow and increased vascular resistance in early Raynaud's disease indicates that some organic obstruction of the small blood vessels may occur very early in the course of the disease. The acute attacks, then, are produced by functional reversible vasoconstriction, superimposed upon whatever organic obstruction is present. In the more advanced stages of Raynaud's disease, secondary sclerodactyly contributes to the further organic constriction of the vascular bed.
In scleroderma, there may be little if any change in the digital circulation in the absence of sclerodactyly. In most cases, however, there is a decrease in digital blood flow and an increase in resistance very early in the course of the disease. In fact, the diagnosis may be established in doubtful cases by demonstrating these changes in the digital circulation. In the very advanced stages, the tight skin may compress the main digital arteries themselves $(5,6)$ and thus produce some decrease in digital arterial pressure and therefore an increased brachial-digital arterial pressure gradient. It is impossible to determine from these investigations to what extent the obstruction of the blood vessels in scleroderma is intravascular or extravascular.

In thrombo-angiitis obliterans, the decrease in digital blood flow was attributable entirely to the decrease in digital arterial pressure, the resistance of the smaller blood vessels being unaffected. The extreme increase in the brachial-digital arterial pressure gradient in these cases was probably caused by vascular obstruction confined to the larger arteries.

\section{SUMMARY AND CONCLUSIONS}

1. The digital circulation was studied in Raynaud's syndrome, scleroderma, and thromboangiitis obliterans.

2. In Raynaud's disease and in scleroderma, the digital blood flow is usually decreased and the digital vascular resistance increased. In thromboangiitis obliterans, the digital blood flow is decreased because of a decrease in digital arterial blood pressure, the digital vascular resistance remaining comparatively unchanged.

3. Study of the digital circulation may be useful as an aid in diagnosis and prognosis, and as an index of the effect of therapy in peripheral vascular diseases involving the upper extremities.

This opportunity is taken of acknowledging the cooperation of Drs. G. Baehr, E. Moschcowitz, E. P. Boas, and S. Silbert in making these cases available for study.

\section{BIBLIOGRAPHY}

1. Mendlowitz, M., The digital blood flow, arterial pressure and vascular resistance in arterial hypertension and in coronary thrombosis. J. Clin. Invest., 1942, 21, 539. 
2. Lewis, T., and Pickering, G. W., Vasodilatation in the limbs in response to warming the body; with evidence for sympathetic vasodilator nerves in man. Heart, 1931, 16, 33.

3. Lewis, T., Experiments relating to the peripheral mechanism involved in spasmodic arrest of the circulation in the fingers, a variety of Raynaud's disease. Heart, 1929, 15, 7.

4. Lewis, T., and Landis, E. M., Further observations upon a variety of Raynaud's disease; with special reference to arteriolar defects and to scleroderma. Heart, 1931, 15, 329.

5. Prinzmetal, M., Studies of the mechanism of circulatory insufficiency in Raynaud's disease in association with sclerodactylia. Arch. Int. Med., 1936, 58, 309.

6. Sodeman, W. A., and Burch, G. E., A direct method for the estimation of skin distensibility with its application to the study of vascular states. J. Clin. Invest., 1938, 17, 785. 